\title{
Improving Sugar Pea Growth and Quality by using some Natural Substances Hala A. El-Sayed ${ }^{1}$; M. A. A. El-Sherbini ${ }^{2}$ and M. T. M. Al-Ashry ${ }^{1}$ \\ ${ }^{1}$ Veg. Flori. Dept., Fac. Agric., Mansoura Univ., Egypt \\ ${ }^{2}$ Veg. Res. Dept., Hort. Res. Inst., Agric. Res. Center, Giza, Egypt
}

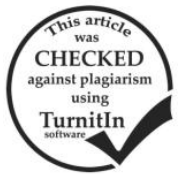

\section{ABSTRACT}

Two field experiments were conducted at Private Farm in Wadi Al-Natroun Distrect, Beheira Governorate, Egypt during Winter seasons of 2016/2017 and 2017/2018, to study the effect of some natural foliar applications, i.e., fulvic acid (20 ml/1), effective microorganisms $(5 \mathrm{ml} / 1)$,yeast extract $(25 \mathrm{ml} / \mathrm{l})$, humic acid $(2 \mathrm{~g} / \mathrm{l})$, brassinolide $(5 \mathrm{mg} / \mathrm{l})$ and chitosan $(200 \mathrm{mg} / \mathrm{l})$ on vegetative growth, pod yield and quality of snow pea cultivar "Snow Wind" and sugar snap pea cultivar "Sugar Snap". The results showed that Sugar Snap cultivar surpassed Snow Wind cultivar in all studied traits, except for number of pods/plant, pod length, pod diameter and protein content. However, all studied natural substances significantly increased vegetative growth, pod yield and pod quality compared with control in both seasons. Foliar applications can be arranged in decreasing order as follows: fulvic acid $>$ effective microorganisms $>$ humic acid $>$ yeast extract $>$ brassinolide $>$ chitosan.

Keywords: sugar pea, fulvic acid, effective microorganisms, yeast extract, humic acid, brassinolide, chitosan, growth, yield, quality

\section{INTRODUCTION}

Sugar pea (Pisum sativum L.) is considered one of the most important vegetable crops belonging to the legume family. It is a seasonal crop in Egypt where it is a winter crop grown for export. Sugar peas include two types: the snow peas (Pisum sativum var. macrocarpon) and the sugar snap peas (Pisum sativum var. saccharatum), they are known as edible-podded peas because they don't have the same cross fiber in the wall of the pod as the conventional pea and pods can be eaten whole. Sugar pea pods contain a great amount of protein, carbohydrates, vitamins, minerals and other nutrients and can be eaten raw, lightly boiled, steamed or used in stri-frys (Burt, 2008).

Agrochemicals are considered as a powerful weapon or magic bullets in the developing countries in order to enhance the agriculture productivity. The excessive and indiscriminate use of agrochemicals, allowing continued environmental contamination and contamination of the human food chain (Wimalawansa and Wimalawansa, 2014).

In recent times, attention has been attracted towards natural growth bio-stimulating compounds, safety to the environment, inexpensive and harmless to humans, for achieving high productivity of vegetables. One of these components is yeast extract, a natural source of cytokinins and has a stimulatory effect on pea plants. It has a beneficial role in stimulating the growth of plants and is one of the richest sources of protein, especially the essential amino acids, the essential minerals and trace elements. It was reported that yeast extract increased plant growth and pod yield of pea plants (Mahmoud et al., 2013). Likewise, chitosan is a natural, low toxic, inexpensive compound and environmentally friendly with various applications in agriculture. It also improves growth and development of tomato plants (El-Tantawy, 2009).

Too, brassinosteroids (BRs) are a group of steroidal plant hormones, has been noted as the sixth plant hormone subsequent to auxin, gibberellin, cytokinin, ethylene and abscisic acid (Hamada, 1986). They were first isolated and characterized from the pollen of rape plant (Brassica napus L.), and are considered as hormones with pleiotropic effects, as they influence varied developmental processes like germination of seeds, growth, rhizogenesis, flowering and senescence. As well as promote elongation of pea plant (Clouse et al., 1992).
Moreover, humic acids (HAs) and fulvic acids (FAs) together are called "humic substances". These substances increase the availability of nutrient elements by promoting the conversion of mineral elements into available forms to plants and they have a role in improving conditions of the plant and increasing the yield and quality of crops (Selim et al., 2009). Also, effective microorganisms (EM) are considered as natural substances where they consist of bacteria, fungus, algae and yeast. EM improve soil health and the growth, yield and quality of vegetable crops (Higa and Parr, 1994).

Therefore, this study aimed to study the effect of some natural bio-stimulants, i.e., fulvic acid, effective microorganisms, yeast extract, humic acid, brassinolide and chitosan on growth, green pod yield and quality of some sugar pea cultivars under sandy soil conditions.

\section{MATERIALS AND METHODS}

Two field experiments were conducted at Private Farm in Wadi Al-Natroun Distrect, Beheira Governorate, Egypt during Winter seasons of 2016/2017 and 2017/2018, to study the effect of some natural foliar applications, i.e., fulvic acid (20 ml/l), effective microorganisms (5 $\mathrm{ml} / \mathrm{l})$,yeast extract $(25 \mathrm{ml} / \mathrm{l})$, humic acid $(2 \mathrm{~g} / \mathrm{l})$, brassinolide $(5 \mathrm{mg} / \mathrm{l})$ and chitosan $(200 \mathrm{mg} / \mathrm{l})$ on vegetative growth, green pod yield and quality of snow pea cultivar "Snow Wind" and sugar snap pea cultivar "Sugar Snap". Representative samples were collected from the experimental soil before sowing at $(0-30 \mathrm{~cm})$ depth to determine some physical and chemical properties as shown in Table (1).

Table 1. Physical and chemical analyses of the soil before conducting the experiment.

\begin{tabular}{lccc}
\hline Properties & Value & Properties & Value \\
\hline Physical & \multicolumn{3}{c}{ Soluble anions (meq/100g soil) } \\
\hline Soil texture & Sandy & $\mathrm{HCO}_{3}^{-}$ & 1.41 \\
Organic matter \% & 0.56 & $\mathrm{CL}^{-}$ & 3.39 \\
Chemical & & $\mathrm{SO}^{--}$ & 1.40 \\
\hline E.C. $(\mathrm{mmohs} / \mathrm{cm})$ & 1.21 & Macro-elements (ppm) \\
\hline pH & 8.13 & $\mathrm{~N}$ & 43.5 \\
C/N ratio & 75.9 & $\mathrm{P}$ & 4.96 \\
\hline Soluble cations (meq/100g soil) & $\mathrm{K}$ & 78.3 \\
\hline $\mathrm{Ca}^{++}$ & 1.29 & & \\
$\mathrm{Mg}^{++}$ & 0.87 & $\mathrm{Micro}^{+}$ & \\
$\mathrm{Na}^{+}$ & 3.76 & $\mathrm{Fe}$ & 2.03 \\
$\mathrm{~K}^{+}$ & 0.28 & $\mathrm{Mn}^{++}$ & 1.40 \\
& & $\mathrm{Zn}^{++}$ & 0.76 \\
\hline
\end{tabular}


Seeds were inoculated directly before sowing with root nodules bacteria (Rhizobium leguminosarum) and were sown as two seeds per hill on one side of the irrigation lines at $20 \mathrm{~cm}$ spacing in $24^{\text {th }}$ and $30^{\text {th }}$ of November in the first and the second seasons, respectively. This experiment included 14 treatments resulted from the combination among 2 cultivars and 7 foliar applications. The layout of the experiment was split-plot system in a randomized complete blocks design with three replicates.

The sugar pea cultivars were randomly occupied the main plots, and the foliar treatments were randomly arranged in the sub-plots. The experimental unit area was $12.0 \mathrm{~m}^{2}$ ( 1 dripper lines, each $12 \mathrm{~m}$ long and $1 \mathrm{~m}$ width). The agricultural practices for sugar pea production were followed according to Egyptian Ministry of Agriculture recommendations. The treatments were sorted as follow:

a. Sugar pea cultivars: Snow Wind and Sugar Snap.

b. Foliar applications:

1- Fulvic acid $(20 \mathrm{ml} / \mathrm{l})$.

2- Effective microorganisms $(5 \mathrm{ml} / \mathrm{l})$.

3- Yeast extract $(25 \mathrm{ml} / \mathrm{l})$.

4- Humic acid (2 g/l).

5- Brassinolide $(5 \mathrm{mg} / \mathrm{l})$.

6- Chitosan $(200 \mathrm{mg} / \mathrm{l})$.

7- Control (sprayed with tap water).

Sugar pea plants were sprayed with foliar treatments three times, 15 days after sowing and repeated each 15 days interval.

Data recorded:

\section{Vegetative growth:}

At 50 days after sowing, five plants from each experimental unit were randomly marked for determining plant height, leaf area/plant $\left(\mathrm{cm}^{2}\right)$ according to Koller (1972) and plant fresh and dry weights (g).

\section{Pod yield and its components:}

At the proper maturing stage, green pods of each experimental unit were harvested, counted and weighted in each harvest and the following parameters were recorded: Number of pods/plant, average weight of pod (gm), pod length $(\mathrm{cm})$, pod diameter $(\mathrm{mm})$, pod thickness $(\mathrm{mm})$, green pod yield/plant (gm) and total green pod yield (ton/fed.).

\section{Chemical composition of pods:}

The following data were determined in pods: Total soluble solids (TSS) was determined by Carl Zeiss refractometer, vitamin $\mathrm{C}(\mathrm{mg} / 100 \mathrm{gfw})$, titrable acidity (\%) and crude fibers (\%) were determined according to (A.O.A.C., 1990), carbohydrates (\%) according to Hedge and Hofreiter (1962) and reducing, non reducing and total sugars (\%) according to Sadasivam and Manickam (1996).

Statistical Analysis:

All obtained data were subjected to the statistical analysis of variance according to Snedecor and Cochran (1968) and treatment means were compared using least significant difference (LSD) method described by Gomez and Gomez (1984) at $5 \%$ significance level. The statistical analyses were performed using CoStat Computer Software program.

\section{RESULTS AND DISCUSSION}

\section{Vegetative growth: \\ 1- Effect of cultivars:}

Data presented in Table (2) show that there were significant differences between Sugar Snap and Snow
Wind cultivars with respect to plant height, leaf area/plant and fresh and dry weight/plant in both seasons. Sugar Snap cultivar had higher values of plant height, leaf area/plant and fresh and dry weight/plant than Snow Wind. In this regard, Weiss et al. (2014) and El- Sherbini (2015) evaluated some varieties of sugar peas and found that there were differences between varieties in their vegetative growth parameters. The differences among cultivars may be due to the different genetic makeup, which affects on growth habit.

\section{2- Effect of foliar applications:}

Table (2) illustrate that all natural substances foliar treatments significantly increased all studied characters compared with the control. The best application was fulvic acid followed by effective microorganisms, humic acid, yeast extract, brassinolide and chitosan, respectively. Similar results were obtained by Abdel-Baky et al. (2019) on faba bean for fulvic acid, Einizadeh and Shokouhian (2019) on strawberry for effective microorganisms, Shafeek et al. (2013) on broad bean for humic acid, Marzauk et al. (2014) on faba bean for yeast extract, Kiera (2018) on snap bean for brasinolide and Sultana et al. (2017) on tomato for chitosan.

The positive effect of fulvic acid on vegetative growth of sugar pea may be due to that fulvic acid accelerates cellular division, stimulates vegetable growth and development, increases cellular energy and regulates plant metabolism to prevent accumulation of nitrate compounds in plants (Jackson, 1993).

Regarding effective microorganism treatment, it improves plant growth by producing bioactive substances such as hormones and enzymes and increasing photosynthesis (Hussain et al., 2002).

In addition, the response of sugar pea growth to yeast extract may attributed to its content of cytokinins which had a stimulatory effect on cell division and enlargement, chlorophyll formation and protein and nuclecic acid synthesis (Spencer et al., 1983).

The positive effect of humic acid on growth may be due to its chemical structure and functional groups, which could interact with harmonic-binding proteins in the membrane system, evoking a hormone-like response (Nardi et al., 1999). Moreover, humic acid increases photosynthesis, stimulates nucleic acid metabolism of tomato (Turkmen et al., 2004).

As for brassinolide involved in cell enlargement process through its effects on gene expression and enzyme activity (Mussig and Altmann, 1999) and promotes lateral root development through increasing acropetal auxin transport (Davidtchuck, 1999) which result in better crop growth.

Concerning chitosan, it had molecular signals that served as plant growth promoters (Hadwiger et al., 2002) and had a role in increasing key enzymes activities of nitrogen metabolism. In addition, it improved nitrogen transportation in the functional leaves which enhanced plant growth and development of okra plants (Mondal et al., 2012).

\section{3- Effect of the interaction:}

As seen in Table (3), the interaction treatments had a positive effect on the studied vegetative growth parameters of sugar pea plants. Spraying Sugar Snap cultivar with fulvic acid accorded the highest values of plant height, leaf area and fresh and dry weigh in both seasons while the lowest values were recorded when Snow Wind sprayed with tap water in both seasons. 
Table 2. Effect of cultivars and foliar applications with some natural substances on plant height, leaf area/plant and fresh and dry weight/plant of sugar pea in the two seasons of 2016/2017 and 2017/2018.

\begin{tabular}{|c|c|c|c|c|c|c|c|c|}
\hline \multirow{2}{*}{ Treatments } & \multicolumn{2}{|c|}{ Plant height (cm) } & \multicolumn{2}{|c|}{ Leaf area/plant $(\mathrm{cm})^{2}$} & \multicolumn{2}{|c|}{ Fresh weight /plant (gm) } & \multicolumn{2}{|c|}{ Dry weight /plant (gm) } \\
\hline & S1 & S2 & S1 & S2 & S1 & S2 & S1 & S2 \\
\hline Sugar Snap & 91.19 & 94.41 & 4666.24 & 5101.19 & 243.80 & 253.04 & 36.15 & 39.82 \\
\hline Snow Wind & 71.61 & 76.29 & 4069.82 & 4569.11 & 179.09 & 185.76 & 25.53 & 27.76 \\
\hline F. test & $* * *$ & $* * *$ & $* * *$ & $* * *$ & $* * *$ & $* * *$ & $* * *$ & $* * *$ \\
\hline Fulvic acid at $(20 \mathrm{ml} / \mathrm{l})$ & 85.76 & 87.93 & 5249.62 & 5623.48 & 237.50 & 243.66 & 38.66 & 41.50 \\
\hline $\mathrm{EM}$ at $(5 \mathrm{ml} / \mathrm{l})$ & 83.53 & 87.65 & 4974.45 & 5271.76 & 234.00 & 239.83 & 35.16 & 38.50 \\
\hline Yeast extract at $(25 \mathrm{ml} / \mathrm{l})$ & 81.38 & 85.10 & 4162.84 & 4930.90 & 211.33 & 220.50 & 30.83 & 35.83 \\
\hline Humic acid at (2g/l) & 82.21 & 86.20 & 4605.66 & 5100.66 & 216.16 & 224.83 & 32.00 & 35.83 \\
\hline Brassinolide at $(5 \mathrm{mg} / \mathrm{l})$ & 80.43 & 84.93 & 4153.44 & 4564.97 & 205.16 & 211.00 & 29.66 & 31.33 \\
\hline Chitosan at $(200 \mathrm{mg} / \mathrm{l})$ & 78.83 & 84.15 & 3964.05 & 4431.61 & 200.83 & 207.83 & 26.00 & 29.00 \\
\hline Control & 77.66 & 81.53 & 3466.17 & 3922.68 & 175.16 & 188.16 & 23.60 & 24.56 \\
\hline$\overline{\text { LSD at } 5 \%}$ & 1.457 & 1.482 & 42.648 & 54.272 & 2.093 & 2.133 & 1.417 & 1.291 \\
\hline
\end{tabular}

S1: 2016/2017season, S2: 2017/2018season, EM: effective microorganisms.

Table 3. Effect of the interaction between cultivars and foliar applications with some natural substances on plant height, leaf area/plant and fresh and dry weight/plant of sugar pea in the two seasons of 2016/2017 and $2017 / 2018$.

\begin{tabular}{|c|c|c|c|c|c|c|c|c|c|}
\hline \multirow{2}{*}{\multicolumn{2}{|c|}{ Treatments }} & \multicolumn{2}{|c|}{ Plant height (cm) } & \multicolumn{2}{|c|}{ Leaf area/plant $(\mathrm{cm})^{2}$} & \multicolumn{2}{|c|}{ Fresh weight/plant (gm) } & \multicolumn{2}{|c|}{ Dry weight /plant (gm) } \\
\hline & & S1 & S2 & S1 & S2 & S1 & S2 & S1 & S2 \\
\hline \multirow{7}{*}{ 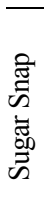 } & Fulvic acid at $(20 \mathrm{ml} / \mathrm{l})$ & 96.33 & 98.2 & 5267.58 & 5698.83 & 274.33 & 276.66 & 45.33 & 47.66 \\
\hline & $\mathrm{EM}$ at $(5 \mathrm{ml} / \mathrm{l})$ & 92.76 & 97.66 & 5209.30 & 5457.81 & 268.66 & 272.66 & 39.33 & 43.33 \\
\hline & Yeast extract at $(25 \mathrm{ml} / \mathrm{l})$ & 91.20 & 93.86 & 5041.07 & 5228.87 & 241.66 & 261.66 & 36.00 & 42.66 \\
\hline & Humic acid at $(2 \mathrm{~g} / \mathrm{l})$ & 91.96 & 95.66 & 5152.92 & 5439.73 & 257.00 & 262.33 & 38.00 & 43.33 \\
\hline & Brassinolide at $(5 \mathrm{mg} / \mathrm{l})$ & 90.10 & 93.33 & 4302.07 & 5015.34 & 233.00 & 241.33 & 35.66 & 37.66 \\
\hline & Chitosan at $(200 \mathrm{mg} / \mathrm{l})$ & 89.00 & 92.10 & 3967.10 & 4539.11 & 233.00 & 241.33 & 30.66 & 34.66 \\
\hline & Control & 87.00 & 90.10 & 3723.67 & 4328.68 & 199.00 & 215.33 & 28.10 & 29.45 \\
\hline \multirow{7}{*}{ 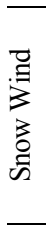 } & Fulvic acid at $(20 \mathrm{ml} / \mathrm{l})$ & 75.20 & 77.66 & 5231.65 & 5548.14 & 200.66 & 210.66 & 32.00 & 35.33 \\
\hline & $\mathrm{EM}$ at $(5 \mathrm{ml} / \mathrm{l})$ & 75.10 & 77.63 & 4795.97 & 5103.78 & 199.33 & 207.00 & 31.00 & 33.66 \\
\hline & Yeast extract at $(25 \mathrm{ml} / \mathrm{l})$ & 71.66 & 76.73 & 4002.02 & 4743.52 & 177.33 & 180.66 & 25.66 & 28.33 \\
\hline & Humic acid at $(2 \mathrm{~g} / \mathrm{l})$ & 72.66 & 76.86 & 4004.81 & 4846.46 & 181.00 & 187.33 & 26.00 & 29.00 \\
\hline & Brassinolide at $(5 \mathrm{mg} / \mathrm{l})$ & 69.66 & 76.20 & 3961.01 & 4590.83 & 175.33 & 179.33 & 23.66 & 25.00 \\
\hline & Chitosan at $(200 \mathrm{mg} / \mathrm{l})$ & 68.66 & 76.00 & 3284.60 & 3634.36 & 168.66 & 174.33 & 21.33 & 23.33 \\
\hline & Control & 66.33 & 72.96 & 3208.68 & 3516.69 & 151.33 & 161.00 & 19.10 & 19.67 \\
\hline$\overline{\mathrm{LS}}$ & $5 \%$ & 2.061 & 2.096 & 60.313 & 76.753 & 2.960 & 3.017 & 2.004 & 1.826 \\
\hline
\end{tabular}

\section{S1: 2016/2017season, S2: 2017/2018season, EM: effective microorganisms.}

\section{Green pod yield and its components: \\ 1- Effect of cultivars:}

Data are presented in Table (4) show that Sugar

Snap cultivar recorded the heaviest average green pod weight, green pod yield/plant and total green pod yield/fed. in the two studied seasons, respectively. In addition, Table (5) clearly show that Snow Wind cultivar recorded the highest values of pod length and pod diameter in both studied seasons, whereas Sugar Snap cultivar recorded the highest values of pod thickness in both seasons.

Similar results were obtained by El- Sherbini (2015) who stated that total green pod yield and its components of sugar pea recorded statistical variations among all the tested varieties.

\section{2- Effect of foliar applications:}

As seen in Table (4), all foliar application with some natural substances significantly affected all studied parameters, i.e., average green pod weight, number of green pods/plant, green pod yield/plant and total green pod yield/fed. compared to control in both seasons of the study.

The heaviest average green pod weight, green pod yield/plant and total green pod yield/fed. were obtained when sugar pea plants sprayed with fulvic acid followed by effective microorganisms, humic acid, yeast extract, brassinolide and chitosan foliar applications in both seasons, respectively.

In addition, Table (5) show that all foliar application with some natural substances had positive effect on pod length, diameter and thickness in both seasons. The highest values in all previous studied characters were obtained when sugar pea plants sprayed with fulvic acid followed by effective microorganisms, humic acid, yeast extract, brassinolide and chitosan, respectively. Moreover, control plants recorded the lowest values in all studied parameters.

These results are in accordance with those obtained by Abdel-Baky et al. (2019) on faba bean for fulvic acid, Einizadeh and Shokouhian (2019) on strawberry for effective microorganisms, Shafeek et al. (2013) on broad bean for humic acid, Marzauk et al. (2014) on faba bean for yeast extract, Kiera (2018) on snap bean for brasinolide and Sultana et al. (2017) on tomato for chitosan.

The promotive effect of fulvic acid on yield may be attributed to increasing chlorophyll content and net photosynthesis rates (Chen et al., 2004) and thereby increased translocation and accumulation of certain metabolites in plant organs.

The favorable effect of effective microorganisms on yield of sugar pea may be due to its effect on flower initiation in legume crops that resulted in increasing number of pods, and hence the total yield was increased (Javaid, 2006).

The positive response of sugar pea yield and its components to yeast extract may be due to its high content of cytokinins, Vit.B, organic compounds and nutrients (Nagodawithana, 1991), which increase distribution and translocation of metabolites from leaves towards the reproductive organs, thereby increasing sugar pea yield.

Increasing sugar pea pod yield in response to humic acid foliar application is a result of its positive physiological effects on cell metabolism and increased chlorophyll concentrations which promotes photosynthetic 
activities which, in turn, diverts more photo-assimilates towards higher number of sinks (Nardi et al., 2002).

Regarding the increase in sugar pea yield in response to brassinolide, it mainly due to the role of brassinolide in increasing the endogenous level of auxins resulting in the enhancement of pod set (Susila et al., 2012).

Concerning the effect of chitosan, it may be a result of protecting plants against microorganisms (Nge et al., 2006), stimulation of roots, shoots and leaves and increasing chlorophyll content and photosynthetic rate (Khan et al., 2002) which led to increasing the vegetative growth followed by active translocation of photoassimilates from source to sink tissues and hence increasing total green yield.

Table 4. Effect of cultivars and foliar applications with some natural substances on number of green pods/plant, average green pod weight, green pod yield/plant and total green pod yield/fed. of sugar pea in the two seasons of 2016/2017 and 2017/2018.

\begin{tabular}{|c|c|c|c|c|c|c|c|c|}
\hline \multirow[t]{2}{*}{ Treatments } & \multicolumn{2}{|c|}{$\begin{array}{c}\text { No of green pods } \\
\text { /plant }\end{array}$} & \multicolumn{2}{|c|}{$\begin{array}{l}\text { Average green pod } \\
\text { weight (gm) }\end{array}$} & \multicolumn{2}{|c|}{$\begin{array}{l}\text { Green pod yield } \\
\text { /plant (gm) }\end{array}$} & \multicolumn{2}{|c|}{$\begin{array}{c}\text { Total green } \\
\text { Pod yield (ton/fed.) }\end{array}$} \\
\hline & S1 & S2 & S1 & S2 & S1 & S2 & S1 & S2 \\
\hline Sugar Snap & 47.04 & 48.04 & 7.36 & 7.45 & 350.81 & 358.43 & 7.016 & 7.168 \\
\hline Snow Wind & 75.52 & 76.90 & 3.43 & 3.49 & 262.91 & 265.08 & 5.258 & 5.301 \\
\hline F. test & $* * *$ & $* * *$ & $* * *$ & $* * *$ & $* * *$ & $* * *$ & $* * *$ & $* * *$ \\
\hline Fulvic acid at $(20 \mathrm{ml} / \mathrm{l})$ & 65.00 & 66.00 & 5.54 & 5.60 & 328.18 & 337.40 & 6.563 & 6.748 \\
\hline $\mathrm{EM}$ at $(5 \mathrm{ml} / \mathrm{l})$ & 63.33 & 64.50 & 5.50 & 5.57 & 323.2 & 328.38 & 6.464 & 6.567 \\
\hline Yeast extract at $(25 \mathrm{ml} / \mathrm{l})$ & 61.33 & 62.16 & 5.39 & 5.45 & 304.76 & 309.60 & 6.095 & 6.192 \\
\hline Humic acid at $(2 \mathrm{~g} / \mathrm{l})$ & 62.16 & 63.33 & 5.46 & 5.50 & 313.47 & 318.37 & 6.269 & 6.367 \\
\hline Brassinolide at $(5 \mathrm{mg} / \mathrm{l})$ & 60.00 & 61.33 & 5.30 & 5.42 & 298.23 & 302.54 & 5.964 & 6.050 \\
\hline Chitosan at $(200 \mathrm{mg} / \mathrm{l})$ & 59.00 & 60.50 & 5.31 & 5.38 & 294.25 & 296.21 & 5.885 & 5.924 \\
\hline Control & 58.16 & 59.50 & 5.26 & 5.37 & 285.96 & 289.79 & 5.719 & 5.795 \\
\hline LSD at $5 \%$ & 1.095 & 0.903 & 0.083 & 0.083 & 3.703 & 4.288 & 0.074 & 0.085 \\
\hline
\end{tabular}

S1: 2016/2017season, S2: 2017/2018season, EM: effective microorganisms.

Table 5. Effect of cultivars and foliar applications with some natural substances on pod length, diameter and thickness of sugar pea in the two seasons of 2016/2017 and 2017/2018.

\begin{tabular}{|c|c|c|c|c|c|c|}
\hline \multirow{2}{*}{ Treatments } & \multicolumn{2}{|c|}{ Pod length $(\mathrm{cm})$} & \multicolumn{2}{|c|}{ Pod diameter (mm) } & \multicolumn{2}{|c|}{ Pod thickness (mm) } \\
\hline & S1 & S2 & S1 & S2 & S1 & S2 \\
\hline Sugar Snap & 7.30 & 7.34 & 13.46 & 13.55 & 12.24 & 12.41 \\
\hline Snow Wind & 9.00 & 9.18 & 18.63 & 18.73 & 3.76 & 3.87 \\
\hline F. test & $* * *$ & $* * *$ & $* * *$ & $* * *$ & $* * *$ & $* * *$ \\
\hline Fulvic acid at $(20 \mathrm{ml} / \mathrm{l})$ & 8.37 & 8.45 & 16.44 & 16.47 & 8.50 & 8.71 \\
\hline $\mathrm{EM}$ at $(5 \mathrm{ml} / \mathrm{l})$ & 8.30 & 8.38 & 16.30 & 16.36 & 8.31 & 8.43 \\
\hline Yeast extract at $(25 \mathrm{ml} / \mathrm{l})$ & 8.19 & 8.27 & 16.01 & 16.16 & 8.07 & 8.15 \\
\hline Humic acid at $(2 \mathrm{~g} / 1)$ & 8.25 & 8.32 & 16.18 & 16.31 & 8.19 & 8.35 \\
\hline Brassinolide at ( $5 \mathrm{mg} / \mathrm{l})$ & 8.18 & 8.25 & 15.95 & 16.05 & 7.87 & 8.02 \\
\hline Chitosan at (200 mg/l) & 8.15 & 8.18 & 15.85 & 15.93 & 7.80 & 7.90 \\
\hline Control & 7.85 & 7.98 & 15.58 & 15.70 & 7.28 & 7.42 \\
\hline LSD at 5\% & 0.049 & 0.046 & 0.078 & 0.068 & 0.085 & 0.099 \\
\hline
\end{tabular}

S1: 2016/2017season, S2: 2017/2018season, EM: effective microorganisms.

Table 6. Effect of the interaction between cultivars and foliar applications with some natural substances on number of green pods/plant, average green pod weight, green pod yield/plant and total green pod yield/fed. of sugar pea in the two seasons of 2016/2017 and 2017/2018.

\begin{tabular}{|c|c|c|c|c|c|c|c|c|c|}
\hline \multirow{2}{*}{\multicolumn{2}{|c|}{ Treatments }} & \multicolumn{2}{|c|}{$\begin{array}{c}\text { No of green pods } \\
\text { / plant }\end{array}$} & \multicolumn{2}{|c|}{$\begin{array}{l}\text { Average green pod } \\
\text { weight (gm) }\end{array}$} & \multicolumn{2}{|c|}{$\begin{array}{l}\text { Green pod yield } \\
\text { /plant (gm) }\end{array}$} & \multicolumn{2}{|c|}{$\begin{array}{l}\text { Total green Pod yield } \\
\text { (ton/fed.) }\end{array}$} \\
\hline & & S1 & S2 & S1 & S2 & S1 & S2 & S1 & S2 \\
\hline \multirow{7}{*}{ 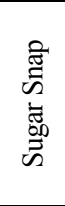 } & Fulvic acid at $(20 \mathrm{ml} / \mathrm{l})$ & 49.66 & 50.66 & 7.56 & 7.63 & 372.53 & 383.36 & 7.450 & 7.667 \\
\hline & EM at $(5 \mathrm{ml} / 1)$ & 48.66 & 49.33 & 7.46 & 7.56 & 368.20 & 376.60 & 7.364 & 7.532 \\
\hline & Yeast extract at $(25 \mathrm{ml} / \mathrm{l})$ & 47.33 & 48.00 & 7.36 & 7.43 & 348.73 & 356.80 & 6.974 & 7.136 \\
\hline & Humic acid at $(2 \mathrm{~g} / \mathrm{l})$ & 48.00 & 49.00 & 7.46 & 7.50 & 358.50 & 367.50 & 7.170 & 7.350 \\
\hline & Brassinolide at ( $5 \mathrm{mg} / \mathrm{l})$ & 46.33 & 47.33 & 7.23 & 7.40 & 342.33 & 350.20 & 6.846 & 7.004 \\
\hline & Chitosan at $(200 \mathrm{mg} / \mathrm{l})$ & 45.33 & 46.66 & 7.26 & 7.33 & 339.03 & 342.16 & 6.780 & 6.843 \\
\hline & Control & 44.00 & 45.33 & 7.20 & 7.33 & 326.4 & 332.43 & 6.528 & 6.648 \\
\hline \multirow{7}{*}{ 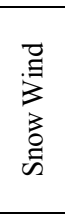 } & Fulvic acid at $(20 \mathrm{ml} / 1)$ & 80.33 & 81.33 & 3.53 & 3.58 & 283.83 & 291.45 & 5.676 & 5.829 \\
\hline & EM at $(5 \mathrm{ml} / 1)$ & 78.00 & 79.66 & 3.51 & 3.56 & 278.2 & 280.16 & 5.564 & 5.603 \\
\hline & Yeast extract at $(25 \mathrm{ml} / \mathrm{l})$ & 75.33 & 76.33 & 3.41 & 3.48 & 260.80 & 262.40 & 5.216 & 5.248 \\
\hline & Humic acid at $(2 \mathrm{~g} / \mathrm{l})$ & 76.33 & 77.66 & 3.46 & 3.51 & 268.45 & 269.25 & 5.369 & 5.385 \\
\hline & Brassinolide at $(5 \mathrm{mg} / \mathrm{l})$ & 73.66 & 75.33 & 3.38 & 3.45 & 254.13 & 254.88 & 5.082 & 5.097 \\
\hline & Chitosan at $(200 \mathrm{mg} / \mathrm{l})$ & 72.66 & 74.33 & 3.36 & 3.43 & 249.48 & 250.26 & 4.989 & 5.005 \\
\hline & Control & 72.33 & 73.66 & 3.33 & 3.41 & 245.53 & 247.15 & 4.910 & 4.943 \\
\hline \multicolumn{2}{|c|}{$\overline{\mathrm{LSD}}$ at $5 \%$} & 1.549 & 1.278 & 0.117 & 0.118 & 5.237 & 6.064 & 0.104 & 0.121 \\
\hline
\end{tabular}

S1: 2016/2017season, S2: 2017/2018season, EM: effective microorganisms.

\section{3- Effect of the interaction:}

Tables (6 and 7) show that different interaction trents between cultivars and foliar treatments had a expressed as average green pod weight, green pod diameter and thickness of sugar pea. The best interaction treatment for pod length and diameter of sugar pea was (Snow wind $\times$ fulvic acid) in the two seasons while the the best interaction treatment for average pod weight, pod yield/plant, total pod yield/fed. and pod thickness of sugar pea was (Sugar snap $\times$ fulvic acid) while the lowest one was (Snow wind $\times$ control) in both seasons.

(1:2016/2017seas, S2: 2017/2018sean, EM: effective microorganisms.

(2) 
Table 7. Effect of the interaction among cultivars and foliar applications with some natural substances on pod length, diameter and thickness of sugar pea in the two seasons of 2016/2017 and 2017/2018.

\begin{tabular}{|c|c|c|c|c|c|c|}
\hline \multirow[t]{2}{*}{ Treatments } & \multicolumn{2}{|c|}{$\begin{array}{l}\text { Pod length } \\
\text { (cm) }\end{array}$} & \multicolumn{2}{|c|}{$\begin{array}{c}\text { Pod } \\
\text { diameter } \\
(\mathbf{m m})\end{array}$} & \multicolumn{2}{|c|}{$\begin{array}{c}\text { Pod } \\
\text { thickness } \\
(\mathbf{m m})\end{array}$} \\
\hline & S1 & S2 & S1 & S2 & S1 & $\mathbf{S 2}$ \\
\hline Fulvic acid at $(20 \mathrm{ml} / \mathrm{l})$ & 7.44 & 7.51 & 13.82 & 13.84 & 12.80 & 13.13 \\
\hline EM at $(5 \mathrm{ml} / \mathrm{l})$ & 7.43 & 7.43 & 13.70 & 13.73 & 12.66 & 12.76 \\
\hline Yeast extract at $(25 \mathrm{ml} / \mathrm{l})$ & 7.26 & 7.33 & 13.40 & 13.66 & 12.31 & 12.37 \\
\hline Humic acid at $(2 \mathrm{~g} / \mathrm{l})$ & 7.36 & 7.40 & 13.63 & 13.70 & 12.51 & 12.70 \\
\hline Brassinolide at ( $5 \mathrm{mg} / \mathrm{l})$ & 7.26 & 7.30 & 13.37 & 13.46 & 12.10 & 12.23 \\
\hline Chitosan at (200 mg/l) & 7.21 & 7.25 & 13.26 & 13.36 & 12.00 & 12.10 \\
\hline & 7.13 & 7.17 & 13.03 & 13 & 11.34 & 11.56 \\
\hline \multirow{8}{*}{ 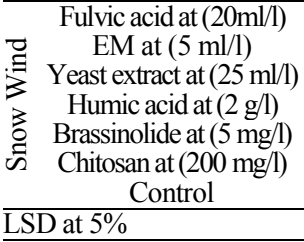 } & 9.30 & 9.40 & 19.06 & 19.10 & 4.20 & 4.30 \\
\hline & 9.16 & 9.33 & 18.90 & 19.00 & 3.96 & 4.10 \\
\hline & 9.12 & 9.21 & 18.63 & 18.66 & 3.83 & 3.93 \\
\hline & 9.14 & 9.23 & 18.73 & 18.93 & 3.86 & 4.00 \\
\hline & 9.11 & 9.20 & 18.53 & 18.63 & 3.65 & 3.82 \\
\hline & 9.10 & 9.11 & 18.43 & 18.49 & 3.60 & 3.71 \\
\hline & 8.58 & 8.80 & 18.13 & 18.28 & 3.21 & 3.28 \\
\hline & 0.069 & 0.065 & 0.110 & 0.097 & 0.121 & 0.140 \\
\hline
\end{tabular}
S1: 2016/2017season, S2: 2017/2018season,

EM: effective microorganisms.

3. Chemical composition of pods:

1- Effect of cultivars:

Table (8) show that Sugar Snap pods recorded the highest values of TSS and vitamin C and the lowest content of fiber and titrable acidity in both seasons.

As for reducing, non-reducing and total sugars contents, data in Table (9) show that the differences between cultivars were significant in the two studied seasons. However, Sugar Snap pods were the highest in aforementioned characters followed by Snow Wind in both seasons.

Similar results were obtained by Weiss et al. (2014) and El- Sherbini (2015) on sugar pea, they showed that sugar pea cultivars differed in their pod chemical composition.

\section{2- Effect of foliar applications:}

Data shown in Table (8) reveal that spraying sugar pea plants with studied natural substances significantly increased TSS and vitamin C and decreased the content of fiber and titrable acidity in pods compared to control in both studied seasons. Humic acid followed by fulvic acid were the best treatments recording the highest content of TSS, vitamin C and the lowest content of fiber and titrable acidity contents in pods. On the other hand, pods of control treatment recorded the lowest total soluble solids (TSS) and vitamin $\mathrm{C}$ content and the highest fiber and titrable acidity content in both studied seasons.
Concerning the effect of foliar applications on reducing, non-reducing and total sugars, Table (9) indicate that previous studied characters significantly affected by foliar applications compared with the control in both season. Sugar pea plants treated with humic acid gave the highest values of reducing, non-reducing and total sugars followed by fulvic acid, effective microorganisms, yeast extract, brassinolide and chitosan, respectively while the lowest content was obtained in control pods.

These results are agreed with those recorded by Abdel-Baky et al. (2019) on faba bean for fulvic acid, Einizadeh and Shokouhian (2019) on strawberry for effective microorganisms, Eid and Abbas (2013) on common beans for humic acid, Marzauk et al. (2014) on faba bean for yeast extract, Kiera (2018) on snap bean for brassinolide and Sultana et al. (2017) on tomato for chitosan.

Additionally, fulvic acid increases the uptake of N, $\mathrm{P}, \mathrm{K}, \mathrm{Ca}, \mathrm{Mg}$ of cucumber (Rauthan and Schnitzer, 1981) and is one of the most efficient transporters of vitamins into the cell (Fahramand et al. 2014).

The positive effect of effective microorganisms on chemical contents of pods may be attributed to that EM are effective during crop production (Ncube, 2008) and enhance photosynthetic, and protein synthetic activity (Olle and Williams, 2013).

The increase of pods chemical content in response to yeast extract might be attributed to its high content of macro and micro nutrients which increases the capacity of plants to absorb nutrients by increasing root surface in soil and building up plant metabolients (Nagodawithana, 1991).

The favorable effect on chemical composition of pods induced by humic acid foliar application might be due to increasing availability of nutrients and accumulation of pigments resulting in greener leaves with greater photosynthetic efficiency which produce more assimilates depicted in terms of total soluble solids (Abdel-Mwgoud et al., 2007).

The positive effects of brassinosteroid (BRs) on chemical content of sugar pea pods may be referring to activation of translational processes of specific stress tolerance genes (Kagale et al., 2007) and increasing nucleic acid and protein synthesis (Kalinich et al., 1985).

Concerning chitosan, its favorable impact on chemical contents of pods might be referred to its high content of amino compounds (Chibu and Shibayama, 2001).

Table 8. Effect of cultivars and foliar applications with some natural substances on fiber, TSS, vitamin C and acidity contents of sugar pea pods in the two seasons of 2016/2017 and 2017/2018.

\begin{tabular}{|c|c|c|c|c|c|c|c|c|}
\hline \multirow{2}{*}{ Treatments } & \multicolumn{2}{|c|}{ Fiber (\%) } & \multicolumn{2}{|c|}{ TSS } & \multicolumn{2}{|c|}{ Vitamin C (mg/100gfw) } & \multicolumn{2}{|c|}{ Acidity (\%) } \\
\hline & S1 & S2 & S1 & S2 & S1 & S2 & S1 & S2 \\
\hline Sugar Snap & 9.15 & 8.70 & 8.55 & 9.38 & 78.17 & 84.60 & 0.439 & 0.397 \\
\hline Snow Wind & 9.57 & 9.39 & 8.03 & 8.91 & 66.94 & 73.80 & 0.453 & 0.405 \\
\hline F. test & $* * *$ & $* * *$ & $* * *$ & $* * *$ & $* * *$ & $* * *$ & $* * *$ & $* * *$ \\
\hline Fulvic acid at $(20 \mathrm{ml} / \mathrm{l})$ & 8.91 & 8.61 & 8.68 & 9.61 & 76.50 & 81.94 & 0.426 & 0.387 \\
\hline $\mathrm{EM}$ at $(5 \mathrm{ml} / \mathrm{l})$ & 9.69 & 9.32 & 8.50 & 9.36 & 75.08 & 80.83 & 0.442 & 0.389 \\
\hline Yeast extract at $(25 \mathrm{ml} / \mathrm{l})$ & 9.53 & 9.24 & 8.30 & 9.30 & 72.00 & 80.06 & 0.443 & 0.391 \\
\hline Humic acid at $(2 \mathrm{~g} / 1)$ & 8.95 & 8.66 & 8.76 & 9.69 & 78.74 & 82.77 & 0.429 & 0.390 \\
\hline Brassinolide at $(5 \mathrm{mg} / \mathrm{l})$ & 9.37 & 9.08 & 8.14 & 9.05 & 71.33 & 79.15 & 0.445 & 0.393 \\
\hline Chitosan at $(200 \mathrm{mg} / \mathrm{l})$ & 9.20 & 8.91 & 8.04 & 8.85 & 69.02 & 77.56 & 0.446 & 0.423 \\
\hline Control & 9.87 & 9.49 & 7.64 & 8.18 & 65.21 & 72.08 & 0.476 & 0.435 \\
\hline LSD at 5\% & 0.035 & 0.039 & 0.053 & 0.105 & 0.695 & 0.541 & 0.003 & 0.001 \\
\hline
\end{tabular}

S1: 2016/2017season, S2: 2017/2018season, EM: effective microorganisms. 
Table 9. Effect of cultivars and foliar applications with some natural substances on reducing, nonreducing and total sugars contents of sugar pea pods in the two seasons of 2016/2017 and $2017 / 2018$.

\begin{tabular}{|c|c|c|c|c|c|}
\hline \multirow[t]{2}{*}{ Treatments } & \multicolumn{2}{|c|}{$\begin{array}{c}\text { Reducing } \\
\text { sugars (\%) }\end{array}$} & \multicolumn{2}{|c|}{$\begin{array}{c}\text { Non-Reducing } \\
\text { sugars }(\%)\end{array}$} & $\begin{array}{c}\text { Total sugars } \\
(\%)\end{array}$ \\
\hline & S1 & S2 & S1 & S2 & $\begin{array}{ll}\text { S1 } & \text { S2 } \\
\end{array}$ \\
\hline Sugar snap & 4.79 & 4.84 & 15.53 & 15.60 & 20.2820 .43 \\
\hline Snow wind & 4.70 & 4.79 & 14.46 & 14.61 & $19.32 \quad 19.41$ \\
\hline F. test & **** & **** & $* * *$ & $* * *$ & *** $\quad * * *$ \\
\hline Fulvic acid at $(20 \mathrm{ml} / \mathrm{l})$ & 5.13 & 5.23 & 15.43 & 15.54 & 20.7320 .82 \\
\hline $\mathrm{EM}$ at $(5 \mathrm{ml} / \mathrm{l})$ & 5.03 & 5.09 & 15.28 & 15.37 & 20.2020 .38 \\
\hline Yeast extract at $(25 \mathrm{ml} / \mathrm{l})$ & 4.78 & 4.85 & 15.04 & 15.18 & 19.9120 .05 \\
\hline Humic acid at $(2 \mathrm{~g} / \mathrm{l})$ & 5.17 & 5.27 & 15.53 & 15.63 & 20.8020 .90 \\
\hline Brassinolide at $(5 \mathrm{mg} / \mathrm{l})$ & 4.59 & 4.65 & 14.82 & 14.97 & 19.5019 .63 \\
\hline Chitosan at $(200 \mathrm{mg} / \mathrm{l})$ & 4.46 & 4.51 & 14.65 & 14.75 & 19.1519 .23 \\
\hline Control & 4.06 & 4.12 & 14.21 & 14.34 & 18.3118 .42 \\
\hline LSD at 5\% & 0.014 & 0.051 & 0.009 & 0.010 & $0.012 \quad 0.029$ \\
\hline
\end{tabular}

S1: 2016/2017season, S2: 2017/2018season,

EM: effective microorganisms.

\section{3- Effect of the interaction:}

Table (10) show the impact of different interactions between cultivars and foliar applications with some natural substances on pods content of fiber, total soluble solids
(TSS), vitamin $\mathrm{C}$ and titrable acidity. The interaction treatment (Sugar snap $\times$ fulvic acid) recorded the highest TSS and vitamin $\mathrm{C}$ content in the two seasons while the lowest one was (Snow wind $\times$ control) in both seasons. But the interaction treatment (Sugar snap $\times$ fulvic acid) recorded the lowest values of fiber and titrable acidity in both season while, the highest one was (Snow wind $x$ control) in both seasons.

Table (11) show that the interaction treatment between Sugar Snap and humic acid recorded the highest values of reducing, non-reducing and total sugars in both season while, the lowest one was (Snow wind $\times$ control) in both seasons.

From the foregoing results, it could be concluded that, sowing sugar pea cultivars, i.e., Snow Wind and Sugar Snap under sandy soil and similar conditions and spraying with fulvic acid at $20 \mathrm{ml} / \mathrm{l}$ or effective microorganisms at $5 \mathrm{ml} / 1$ or humic acid at $2 \mathrm{~g} / \mathrm{l}$, three times, i.e., 15 days after sowing then repeated each 15 days interval was able to achieve the highest productivity and produced high quality of sugar pea.

Table 10. Effect of the interaction between cultivars and foliar applications with some natural substances on fiber, TSS, vitamin C and acidity contents of sugar pea pods in the two seasons of 2016/2017 and 2017/2018.

\begin{tabular}{|c|c|c|c|c|c|c|c|c|c|}
\hline \multirow{2}{*}{\multicolumn{2}{|c|}{ Treatments }} & \multicolumn{2}{|c|}{ Fiber (\%) } & \multicolumn{2}{|c|}{ TSS } & \multicolumn{2}{|c|}{ Vitamin C (mg/100gfw) } & \multicolumn{2}{|c|}{ Acidity (\%) } \\
\hline & & S1 & S2 & S1 & S2 & S1 & S2 & S1 & S2 \\
\hline \multirow{7}{*}{ 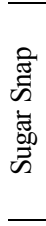 } & Fulvic acid at $(20 \mathrm{ml} / \mathrm{l})$ & 8.70 & 8.31 & 9.03 & 9.88 & 82.55 & 88.26 & 0.412 & 0.384 \\
\hline & EM at $(5 \mathrm{ml} / \mathrm{l})$ & 9.53 & 9.02 & 8.75 & 9.66 & 81.15 & 86.08 & 0.440 & 0.384 \\
\hline & Yeast extract at $(25 \mathrm{ml} / \mathrm{l})$ & 9.34 & 8.90 & 8.53 & 9.58 & 77.11 & 85.34 & 0.440 & 0.384 \\
\hline & Humic acid at (2 g/l) & 8.64 & 8.25 & 9.03 & 9.91 & 84.22 & 89.38 & 0.412 & 0.384 \\
\hline & Brassinolide at (5 mg/l) & 9.16 & 8.75 & 8.25 & 9.26 & 76.44 & 84.15 & 0.440 & 0.384 \\
\hline & Chitosan at (200 mg/l) & 8.99 & 8.57 & 8.25 & 9.16 & 76.03 & 83.97 & 0.461 & 0.419 \\
\hline & Control & 9.71 & 9.12 & 8.03 & 8.21 & 69.71 & 75.02 & 0.469 & 0.440 \\
\hline \multirow{7}{*}{ 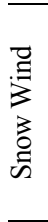 } & Fulvic acid at $(20 \mathrm{ml} / \mathrm{l})$ & 9.13 & 8.92 & 8.33 & 9.33 & 70.45 & 75.63 & 0.441 & 0.391 \\
\hline & EM at $(5 \mathrm{ml} / \mathrm{l})$ & 9.86 & 9.63 & 8.25 & 9.06 & 69.01 & 75.58 & 0.445 & 0.394 \\
\hline & Yeast extract at $(25 \mathrm{ml} / \mathrm{l})$ & 9.73 & 9.58 & 8.06 & 9.03 & 66.89 & 74.78 & 0.447 & 0.398 \\
\hline & Humic acid at $(2 \mathrm{~g} / \mathrm{l})$ & 9.27 & 9.08 & 8.50 & 9.46 & 73.26 & 76.15 & 0.446 & 0.397 \\
\hline & Brassinolide at $(5 \mathrm{mg} / \mathrm{l})$ & 9.58 & 9.41 & 8.03 & 8.83 & 66.22 & 74.16 & 0.451 & 0.402 \\
\hline & Chitosan at (200 mg/l) & 9.42 & 9.25 & 7.83 & 8.53 & 62.01 & 71.15 & 0.453 & 0.406 \\
\hline & Control & 10.04 & 9.87 & 7.25 & 8.16 & 60.72 & 69.15 & 0.492 & 0.451 \\
\hline \multicolumn{2}{|c|}{ LSD at $5 \%$} & 0.050 & 0.055 & 0.075 & 0.142 & 0.983 & 0.750 & 0.005 & 0.002 \\
\hline
\end{tabular}

S1: 2016/2017season, S2: 2017/2018season, EM: effective microorganisms.

Table 11. Effect of the interaction between cultivars and foliar applications with some natural substances on reducing, non-reducing and total sugars contents of sugar pea pods in the two seasons of 2016/2017 and 2017/2018.

\begin{tabular}{|c|c|c|c|c|c|c|c|}
\hline \multirow{2}{*}{\multicolumn{2}{|c|}{ Treatments }} & \multicolumn{2}{|c|}{ Reducing sugars (\%) } & \multicolumn{2}{|c|}{ Non-Reducing sugars (\%) } & \multicolumn{2}{|c|}{ Total sugars (\%) } \\
\hline & & S1 & S2 & S1 & S2 & S1 & S2 \\
\hline \multirow{7}{*}{ 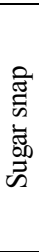 } & Fulvic acid at $(20 \mathrm{ml} / \mathrm{l})$ & 5.21 & 5.28 & 15.97 & 16.02 & 21.25 & 21.35 \\
\hline & $\mathrm{EM}$ at $(5 \mathrm{ml} / \mathrm{l})$ & 5.04 & 5.08 & 15.82 & 15.87 & 20.56 & 20.83 \\
\hline & Yeast extract at $(25 \mathrm{ml} / \mathrm{l})$ & 4.82 & 4.88 & 15.57 & 15.68 & 20.38 & 20.56 \\
\hline & Humic acid at (2 g/l) & 5.28 & 5.32 & 16.09 & 16.14 & 21.31 & 21.42 \\
\hline & Brassinolide at ( $5 \mathrm{mg} / \mathrm{l})$ & 4.65 & 4.69 & 15.33 & 15.47 & 19.98 & 20.15 \\
\hline & Chitosan at (200 mg/l) & 4.47 & 4.51 & 15.19 & 15.23 & 19.67 & 19.76 \\
\hline & Control & 4.09 & 4.13 & 14.73 & 14.83 & 18.83 & 18.94 \\
\hline \multirow{7}{*}{ 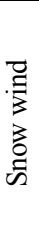 } & Fulvic acid at $(20 \mathrm{ml} / \mathrm{l})$ & 5.05 & 5.17 & 14.90 & 15.06 & 20.21 & 20.29 \\
\hline & $\mathrm{EM}$ at $(5 \mathrm{ml} / \mathrm{l})$ & 5.02 & 5.11 & 14.74 & 14.87 & 19.85 & 19.93 \\
\hline & Yeast extract at $(25 \mathrm{ml} / \mathrm{l})$ & 4.75 & 4.82 & 14.52 & 14.68 & 19.44 & 19.54 \\
\hline & Humic acid at (2 g/l) & 5.05 & 5.21 & 14.98 & 15.12 & 20.29 & 20.38 \\
\hline & Brassinolide at ( $5 \mathrm{mg} / \mathrm{l})$ & 4.54 & 4.62 & 14.31 & 14.47 & 19.03 & 19.12 \\
\hline & Chitosan at (200 mg/l) & 4.45 & 4.51 & 14.11 & 14.26 & 18.63 & 18.71 \\
\hline & Control & 4.04 & 4.10 & 13.69 & 13.85 & 17.8 & 17.90 \\
\hline LSL & & 0.020 & 0.072 & 0.014 & 0.015 & 0.017 & 0.041 \\
\hline
\end{tabular}

S1: 2016/2017season, S2: 2017/2018season, EM: effective microorganisms. 


\section{REFERENCES}

A.O.A.C. (1990). Association of Official Agricultural Chemists. Methods of analysis, 15thedition, Washington, D.C. USA.

Abdel-Baky, Y. R., Abouziena, H. F., Amin, A. A., Rashad, M. and Abd El-Sttar, A. M. (2019). Improve quality and productivity of some faba bean cultivars with foliar application of fulvic acid. Bulletin of the National Research Centre, pp: 1-11.

Abdel-Mawgoud, A.M.R., El-Greadly, N.H.M., Helmy, Y.I and Singer, S.M. (2007). Response of tomato plants to different rates of humic based fertilizer and NPK fertilization. J Appl. Sci. Res., 3: 169-174.

Burt, J. (2008). Growing snow peas and sugar snaps in Western Australia. www. Agric .wa. gov.au /content/hort/veg/cp peas/F05099.pdf.

Chen, Y., Clapp C.E. and Magen, H. (2004). Mechanisms of plant growth stimulation by humic substances: the role of organo-iron complexes. Soil Sci. Plant Nutr., 50: 1089-1095.

Chibu, H. and Shibayama, H. (2001). Effects of chitosan applications on the growth of several crops. In: Uragami, T., Kurita, K. and Fukamizo, T. (Eds.), Chitin and chitosan in life science. Yamaguchi, pp: 235-239.

Clouse, S. D., Zurek, D. M., McMorris, T. C. and Baker, M. E. (1992). Effect of brassinolide on gene expression in elongating soybean epicotyls. Plant Physiol., 100: 1377-1388.

Davidtchuck, N.V. (1999). Effect of various epin treatment methods on growth of seedlings of sugar beet and maize In: Shevelucha, V.S., Karlov, G.I., Karsunkina, N.P., Salnikova, E.I., Skorobogatova, I.V. and Siusheva, A.G., (Eds), Regulators of plant growth and development. Moscow, Agricultural Academy, 89.

Eid, K. E. and Abbas, M. H. H. (2013). Safety chemicals as tools for improving the nutritional status and inducing phyto-resistance of common beans grown in soil infected with Sclerotium rolfsii. J. Appli. Sci. Res., 9(8): 5283-5293.

Einizadeh, S. and Shokouhian, A. A. (2019). The effect of biofertilizer and nitrogen rates on quantitative and qualitative properties of strawberry cultivar 'Paros'. Journal of Central European Agriculture, 19(3): 517-529.

El-Sherbini, M. A. A. (2015). Physiological studies on sugar pea (Pisum sativum L.). Ph.D. Thesis, Fac. Agric., Mansoura Univ., Egypt, 107p.

El-Tantawy, E.M. (2009). Behaviour of tomato plants as affected by spraying with chitosan and aminofortas natural stimulator substances under application of soil organic amendments. Pakistan J. Biol. Sci., 12: 1164-1173.

Fahramand, M., Moradi, H., Noori, M., Sobhkhizi, A., Adibian, M., Abdollahi, S. and Rigi, K. (2014). Influence of humic acid on increase yield of plants and soil properties. Intl. J. Farm. \&Alli.Sci., 3(3): 339-341.

Gomez, K.A. and Gomez, A.A. (1984). Statistical procedures for agricultural research.John Wiley and Sons, Inc., $680 \mathrm{pp}$.

Hadwiger, L.A., Klosterman, S.J. and Choi, J. J. (2002). The mode of action of chitosan and its oligomers in inducing plant promoters and developing disease resistance in plants. In: Suchiva, K., Chandrkrachang, S., Methacanon, P. and Peter, M.G. (Eds.), Advances in chitin science. Bangkok, pp: 452-457.
Hamada, K. (1986). Brassinolide in crop cultivation. In: Macgregor, P. (Ed.), Plant Growth Regulators in Agriculture. Food and Fertilizer Technology Center for the Asian and Pacific Region, Taipei, Taiwan ROC, pp: 190-197.

Hedge, I. E. and Hofreiter, B. T. (1962). Carboydrate Chemistry i7 (Eds Whistler R.L. and Be Miller, J.N.) Academic Press New York.

Higa, T. and Parr, J. F. (1994). Beneficial and effective microorganisms for a sustainable agriculture and environment. International Nature Farming Research Center, Atami, Japan., 1-16 p.

Hussain, T., Anjum, A.D. and Tahir, J. (2002).Technology of beneficial micro-organisms, Nat. Farming Environ., 3: 1-14.

Jackson, W. R. (1993). Humic, fulvic, and microbial balance: Organic soil conditioning, Jacks. Res. Cent., 958 p.

Javaid, A. (2006). Foliar application of effective microorganisms on pea as an alternative fertilizer. Agron. Sustain. Dev., 26: 257-262.

Kagale, S. Divi, U. K., Krochko, J. E., Keller, W. A. and Krishna, P. (2007). Brassinosteroids confer resistance to Arabidopsis thaliana and Brassica napus to a range of abiotic stresses. Planta, 225(2): 353-364.

Kalinich, J. F., Mandava, N. V. and Todhunter, J. A. (1985). Relationship of nucleic acid metabolism to brassinolide induced responses in beans. J. Plant Physiol., 120: 207-214.

Khan, W.M., Prithiviraj, B. and Smith, D.L. (2002). Effect of foliar application of chitin and chitosan oligosaccharides on photosynthesis of maize and soybean. Photosynthetica, 40(4): 621-624.

Kiera, R. M. M. (2018). Effect of organic fertilization and some natural substances on growth, yield and quality of snap bean. M .Sci. Thesis, Fac. Agric., Mansoura Univ., Egypt, 67p.

Koller, H. R. (1972). Leaf area - leaf weight relationship in the soybean canopy . Crop. Sci., $12(3 / 4): 180$ 183.

Mahmoud, R. A., El-Desuki, M., Abdel-Mouty, M. M. and Ali, A. H. (2013). Effect of compost levels and yeast extract application on the pea plant growth, pod yield and quality. Journal of Applied Sciences Research, 9(1): 149-155.

Marzauk, N. M., Shafeek, M. R., Helmy, Y. I., Ahmed, A. A. and Shalaby, M. A. F. (2014). Effect of vitamin $\mathrm{E}$ and yeast extract foliar application on growth, pod yield and both green pod and seed yield of broad bean (Vicia faba L.). Middle East J. Appl. Sci., 4(1): 61-67.

Mondal, M. M. A., Malek, M. A., Puteh, A. B., Ismail, M. R., Ashrafuzzaman, M. and Naher, L. (2012). Effect of foliar application of chitosan on growth and yield in okra. Australian Journal of Crop Science, 6(5): 918-921.

Mussig C. and Altmann T. (1999). Physiology and molecular mode of action of brassinosteroids. Plant Physiology and Biochemistry, 37: 363-372.

Nagodawithana, W.T. (1991). Yeast technology. Universal Foods Corporation Milwaukee, Wisconsin, VauNostrand Reinhold, New York. 273 p.

Nardi, S., Pizzeghello, D., Muscolo, A. and Vianello, A. (2002) Physiological effects of humic substances on higher plants. Soil Biology and Biochemistry, 34: 1527-1536. 
Nardi, S., Pizzeghello, D., Renero, F. and Muscobo, A. (1999). Biological activity of humic substances extracted from soil under different vegetation cover. Commun.Soil.Plant Anal., 30: 621-664.

Ncube, N. (2008). Evaluation of effective microorganisms (EM) on soil chemical properties and yield of selected vegetables in the Eastern Cape, South Africa. M.Sc. Thesis. Department of Agronomy, School of Agriculture and Agribusiness, Faculty of Science and Agriculture, University of Fort Hare, Alice, South Africa, $156 \mathrm{p}$.

Nge, K.L., New, N., Chandrkrachang, S. and Stevens, W.F. (2006). Chitosan as a growth stimulator in orchid tissue culture. Plant Science, 170: 11851190.

Olle, M. and Williams, I. H. (2013). Effective microorganisms and their influence on vegetable production - A review. Journal of Horticultural Science \& Biotechnology, 88(4): 380-386.

Rauthan, B.S. and Schnitzer, M. (1981). Effects of a soil fulvic acid on the growth and nutrient content of cucumber (Cucumis sativus) plants. Plant Soil, 63: 491-495.

Sadasivam, S. and Manickam, A. (1996). Biochemical methods. $2^{\text {nd }}$ edition, New Age International $(p)$ Ltd. New Delhi.

Selim, E.M., Mosa, A.A. and El-Ghamry, A.M. (2009). Evaluation of humic substances fertigation through surface and subsurface drip irrigation systems on potato grown under Egyptian sandy soil conditions. Agr. Water Manage., 96: 1218-1222.

Shafeek, M. R., Helmy, Y. I., Omer, N. O. and Rizk, F. A. (2013). Effect of foliar fertilizer with nutritional compound and humic acid on growth and yield of broad bean plants under sandy soil conditions. J. Appl. Sci. Res., 9(6): 3674-3680.
Snedecor, G.W. and Cochran, W.G. (1968). Statistical Methods. Lowa State.Univ.Press, Ame., USA, $6^{\text {th }}$ Ed., 393 pp.

Spencer, T. F. T., Dorothy, S. M. and Smith, A. R. W. (1983). Yeast genetics, fundamental and applied aspects. Springer- Verlag, New York, USA., pp:1618.

Sultana, S., Islam, M., Khatun, A., Hassain, A. and Huque, R. (2017). Effect of foliar application of oligochitosan on growth, yield and quality of tomato and eggplant. Asian J. Agric. Res., 11: 36-42.

Susila, T., Reddy, S.A., Rajkumar, M., Padmaja, G. and Rao, P.V. (2012). Effects of sowing date and spraying of brassinosteroid on yield and fruit quality characters of watermelon. World J. Agric. Sci., 8 (3): 223-228.

Turkmen O., A. Dursun, M. Turan and C. Erdinc. (2004). Calcium and humic acid affect seed germination, growth, and nutrient content of tomato (Lycopersicon esculentum L.) seedlings under saline soil conditions. Acta Agriculturae Scandinavica, Section B - Soil and Plant Science, 54: 168-174.

Weiss, S.A., Geiger, T.C. and Beamer, K.P. (2014). Evaluation of six edible-pod pea varieties as a potential high value crop for the U.S. Virgin Islands. 50 Annual Meeting Caribbean Food Crops Society, pp: 64.

Wimalawansa, S.A. and Wimalawansa, S.J. (2014). Impact of changing agricultural practices on human health: chronic kidney disease of multi-factorial origin in Srilanka. Wudpecker Journal of Agricultural Research, 3(5): 110-124.

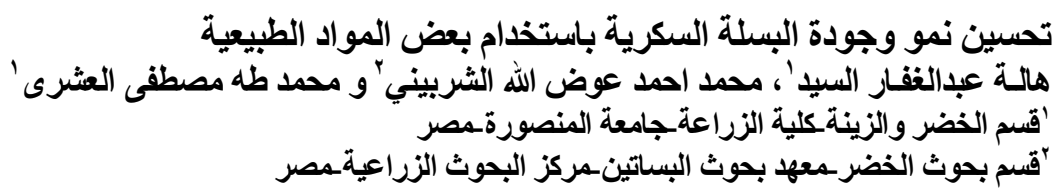

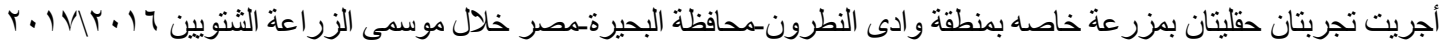

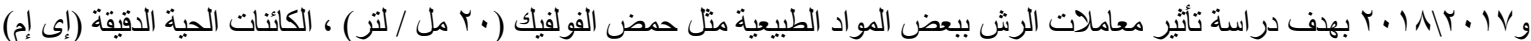

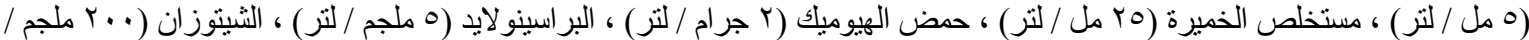

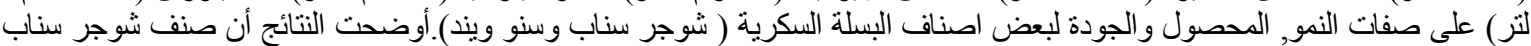

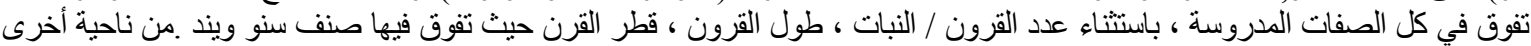

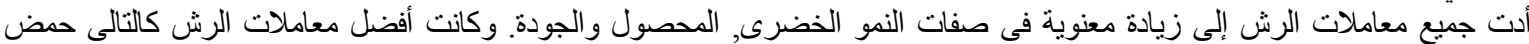

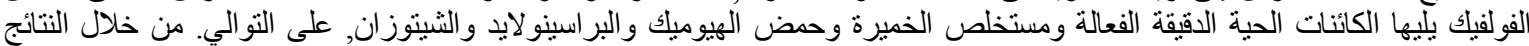

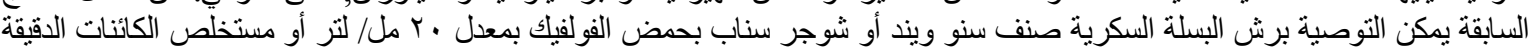

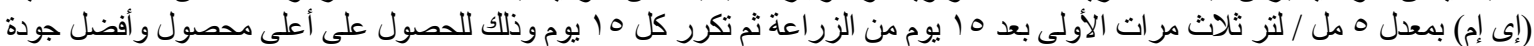
تحت ظروف الأرض أرغد مل الرملية. 